\title{
Conceptual principles of the creation of the high court of intellectual property in Ukraine
}

\author{
V. V. Kuryava \\ Chair of Administrative, Commercial law and financial and economic security, Educational scientific Institute of Law,
} Sumy State University, Sumy, Ukraine; e-mail: viktoria.kuriawa@ukr.net;

Paper received 10.01.19; Accepted for publication 18.01.19.

\section{https://doi.org/10.31174/SEND-HS2019-192VII32-10}

\begin{abstract}
The article analyzes the conceptual foundations of the creation of the High Court of Intellectual Property in Ukraine, exercising their influence on the actual state of implementation of the declared concept of implementation of the Institute of the Protection of Intellectual Property Rights in Ukraine. The actual problems of the practical implementation of the newly created court show the disadvantages of the principles of its creation, the lack of a clear concept and strategy. Such a state of affairs needs an immediate solution to it, since today the basic principle - access to justice in the field of the protection of intellectual property rights is violated, that is inadmissible for a law-governed state.
\end{abstract}

Keywords: the High Court of Intellectual Property in Ukraine, judicial protection of intellectual property rights, jurisdiction of the court.

Introduction. The current state of economic, political, social and legal life in Ukraine is characterized by sharp rejection by the people of our state from the proposed and initiated reforms. Separate hasty decisions of the President and the legislator led to the suspension of the reform of the institute of judicial protection of intellectual property rights, since unresolved issues regarding the legal status of the newly created court led to the impossibility of its practical activity. Due to the lack of unity of strategy and concepts of the development of the legal system, the judicial system and the legal system, there are problems of practical implementation of the steps taken to reform the Institute for the Protection of Intellectual Property Rights.

Analysis of publications. In recent years, scientists have intensified their attention to the newly created court, they considered the issues of the administrative and legal status of the High Court of Intellectual Property (in particular, Koval I., M.I. Logvinenko, Oryluk O.P.), and criminal-law protection of intellectual property rights property in the context of judicial reform (A.O. Dihtiar), certain aspects of the creation of the said court were examined in the investigated Kanarik Yu.S. Mentioned indicates a few studies in this area, and the problem of the formation and functioning of the High Court of intellectual property requires comprehensive, thorough, deep scientific and theoretical research.

Problem statement. The purpose of the article is to identify the conceptual foundations and preconditions for formation of the High Court of Intellectual Property and legal support of its activity in the judicial system of our state. In order to achieve the goal, the following tasks need to be fulfilled: to define the concept of the judicial system of Ukraine and its structure, to determine the place and role in this structure of the newly created High Court of intellectual property issues. Consider the main conceptual framework on the basis of which the High Court of Intellectual Property has been established, which today has its influence on the practical implementation of the decision made by the head of state on the establishment of a court.

Presentation of main material. The basic conceptual framework, the proposed reform of the judiciary and the judiciary, is the irrevocable observance of the principle of the division of state power into branches and the real maintenance of the mechanism of containmentcounterweight. The constitutional principles of the separation of powers in Ukraine are the independence of the judiciary, which is exercised by independent and impartial tribunals. The courts of Ukraine form a unified system of judicial system of our state. The conceptual foundations and content of any reform carried out in the state should be the assertion of human rights and citizenship, as the main duty of the state, declaring itself legal. The main criteria of the rule of law are the priority of human rights in the system of law, the guarantee and reality of the provision of these rights and freedoms, the existence of the institution of civil society, the rule of law. The fundamental task of the courts is to protect the rights and freedoms of man and citizen, and the implementation of this protection can affect any sphere of public relations, in particular, the scope of protection of intellectual property rights, whose protection is gaining increasing importance due to the growth of the role and value of objects of law intellectual property in the modern world and economic space. The legal regulation of the activities of the courts is regulated by an extremely large number of legal acts, since the activities of the judicial branch of government are socially important and necessary. The number of such legal acts can not even be clearly and specifically defined, because the activities of the judiciary cover all spheres of human life. And hence, the wide range of application of the legislative framework is explained. Such activity requires comprehensive regulation starting from the order of creation of judicial bodies, their powers, tasks, competencies, functions - in order to ensure their activities (legal regulation, material financial basis, staffing, etc.). These problematic aspects of organizational and procedural legal support that the newly formed the High Court of Intellectual Property has faced today.

With regard to the development of the current state of legal regulation in the field of protection and protection of intellectual property rights, expresses his position, D. V. Dovgan, in particular, the author comes to the conclusion that especially the precise regulation requires a procedural scope of consideration and resolution of disputes on intellectual property issues. According to the author, the analysis of the process of formation of the legislation of inde- 
pendent Ukraine in the field of intellectual property testifies to the following features. On the one hand, it is the extraordinary dynamism of this process: every year changes are made to the current legislation, which is conditioned both by Ukraine's commitments to the EU and the WTO, and the specificity of this rapidly expanding sphere in the 21 st century. On the other hand, in spite of the annual additions, there are no significant changes in the legal regulation of intellectual property rights relations as such, especially as regards the scope of judicial protection. The process of adaptation of national legislation to EU legislation is extremely slow and mainly under the influence of external factors caused by aggression against our state. Terms of adaptation of intellectual property legislation to the EU legislation, as defined in a series of agreements, were not respected. The presence of a large number of problems in the system of intellectual property rights is due to inconsistency between normative and legal acts on these issues [3, p. 10-11]. The TRIPS Agreement stipulates the standards agreed upon by the WTO member countries as minimum requirements for the legal protection of intellectual property. All WTO members, as well as those countries that wish to become members of the future, must adhere to these standards. Of particular importance in today's conditions is the Association Agreement, Chapter 9 and it's devoted to issues of intellectual property [1]. The main purpose of this chapter is to facilitate the creation and commercial use of innovative products and products of creative activity in the territory of the Parties. The Association Agreement sets standards for the protection of intellectual property rights, which should be observed by the Parties. The analysis of the Association Agreement suggests that all measures aimed at improving the national system of legal protection of intellectual property are aimed at creating comfortable conditions for commercial use of intellectual property rights, prevention of abuse of rights, and unfair practices. The TRIPS Agreement and the Association Agreement require an immediate increase in the level of protection of intellectual property rights in order to secure opportunities for the creation of intellectual property rights and the free use of rights to these objects in business. A. O. Digtyar and A. M. Klochko stressed that «the appropriate level of judicial protection of intellectual property rights will help to increase the attention of foreign investors to Ukraine, since the provision of the intellectual property rights of the owner of a trademark, product or work will not only guarantee their high quality, but also obtain a legitimate income from their implementation and consumption» [2], which is a very important factor in ensuring the economic security of the state.

The main conceptual framework of judicial reform in Ukraine is to ensure an effective and fair judicial protection of human and civil rights. It is the real possibility and mechanism for the protection of human rights and interests in any sphere, including the field of intellectual property law, which determines the right of access to justice, which is recognized by the international community as one of the fundamental ones. Analyzing, the present state of judicial reform, O. Gumega, notes that among the conceptual changes that are being carried out in the direction of judicial reform, effective protection of rights is defined as a priority task of judicial proceedings. After all, a fair, impartial and timely resolution of disputes has been determined in order to effectively protect the rights and legitimate interests of individuals. At the same time, when making procedural decisions and applying any procedural norms, the court must be guided, first of all, precisely by this task of judicial proceedings [5, p. 89]. Therefore, we emphasize once again the need for the procedural provision of the newly created High Court on Intellectual Property.

If we look at the official understanding of the judicial protection of intellectual property rights, which is provided in the Civil Code of Ukraine, namely Art. 432, entitled "Protection of Intellectual Property Rights by the Court". The content of this article is that everyone is guaranteed the right to apply to the court for the protection of their intellectual property rights. In one of the ways a person may exercise the right to protect his or her rights is determined by Article 16 of the Civil Code. The legal consequences of such appeal may be the following court decision regarding: 1) the application of immediate measures to prevent the violation of the intellectual property right and the preservation of relevant evidence; 2) stopping the passage through the customs border of Ukraine of goods the import or export of which is carried out in violation of intellectual property rights; 3) removal from the civil circulation of goods manufactured or introduced into civil circulation in violation of intellectual property rights; 4) removal from the civil circulation of materials and implements used mainly for the manufacture of goods in violation of intellectual property rights; 5) application of one-time money collection instead of indemnification for the unlawful use of the object of intellectual property rights [7]. The amount of the penalty is determined in accordance with the law, taking into account the fault of the person and other circumstances of significant significance; 6) the publication in the mass media of information about the violation of intellectual property rights and the content of the court decision on such violation. However, again, there is a problem of procedural provision of these rights, since the norms of the Criminal Code of Ukraine do not contain any mention of the possibility of considering cases of intellectual property in the order of civil proceedings.

Instead, such an opportunity is provided for by the applicable Commercial Procedural Code of Ukraine. Thus, according to Part 2 of Art. 20 of the Commercial Procedural Code of Ukraine, the High Court of Intellectual Property shall consider cases concerning intellectual property rights, in particular:

1) cases in disputes concerning the rights to an invention, utility model, industrial design, trade mark (mark for goods and services), commercial name and other intellectual property rights, including the right of prior use;

2) cases in disputes concerning the registration, registration of intellectual property rights, invalidation, extension of validity, early termination of patents, certificates, other acts that certify or on the basis of which such rights arise, or which violate such rights or the related law interests;

3) cases of recognition of a trademark well-known;

4) cases in disputes concerning the rights of the author and related rights, including disputes concerning the col- 
lective management of property rights of the author and related rights;

5) cases in disputes regarding the conclusion, modification, termination and execution of an agreement on the disposal of intellectual property rights, commercial concessions;

6) cases in disputes arising out of relations related to protection against unfair competition in relation to: the misuse of signs or goods of another manufacturer; copy the appearance of the product; collection, disclosure and use of commercial secrets; Appeal against decisions of the Antimonopoly Committee of Ukraine on issues specified by this item [4]. However, the analysis of the above norms makes it possible to draw attention to the fact that the jurisdiction of the newly established court does not cover the full completeness of public relations in the field of protection of intellectual property rights, in particular Part 2 of Art. 21 of the Code of Civil Procedure of Ukraine does not contain all possible disputes in this area (taking into account the types of disputes stipulated by special legislation in certain areas of intellectual property - copyright, patent law, means of individualization, etc.). In addition, attention is drawn to the absence of the design of non-retaliatory proceedings in the GPC. In particular, the question of the procedural mechanism of recognition of a trademark is not well-known, which in any circumstances can not be a lawsuit.

If you look at the international experience of judicial protection of intellectual property rights, one can conclude that there are different variations in the world of specialized judicial institutions that deal with intellectual property issues with different names: Specialized IPR Trial Court, Specialized IPR Appeals Court, Specialized IPR Trial Division, Specialized IPR Appeals Division, Commercial Trial Court, Commercial Appeals Court, Trial Court that Exclusively Hears IPR Cases, Appeals Court that Exclusively Hears IPR Cases, Administrative Tribunal, Specialized Judges on Courts of General Jurisdiction, Considering Specialized IPR Court, Division, or Tribunal, Considering Commercial Court. In some countries, no court has exclusive jurisdiction over all IPR matters. For example, in the United Kingdom, the Copyright Tribunal decides the terms and conditions of licenses offered by the collective licensing bodies. By statute, the tribunal is charged with establishing the facts of a case and then deciding upon them. Its decisions may be appealed to the High Court, but only on points of law. In addition, the United Kingdom has two other courts of first instance which adjudicate IPR disputes: the Patents Court, which is part of the Chancery Division of the High Court, and the Patents County Court. The Court of Appeals hears appeals from both courts. All of the judges from both the Patents Court and the Patents County Court are specialists. There is also a special patents judge in the Court of Appeals. The laws that govern IPR are complex, and the technologies protected by those laws can be even more complex. Due to these intricacies, highly experienced judges are often needed to assure timely adjudication and accurate, consistent case outcomes. Although the creation of a specialized IPR court, on its own, does not ensure that judges will be competent in those matters, specialized IPR courts increase judicial exposure to IPR law by funneling cases to a limited number of judges. Specialized IPR courts also facilitate the appointment of judges with specialized knowledge of IPR issues. This should result in higher quality opinions and a more consistent body of law [6].

Regardless of the name, in Ukraine it is necessary to resolve the issue of jurisdiction of the newly created court and its procedural safeguards, to improve the current legal regulation for ensuring the unity of the court practice in the consideration of disputes on intellectual property issues.

Conclusions Thus, based on the above analysis of the understanding of the notion of judicial protection of intellectual property rights, it can be said that it is foreseen by the norms of the current legislation that everyone can apply for the protection of their right to a court, as well as determine the competence of the court in resolving disputes on intellectual property issues. Over the years of our country's independence, the long-standing process of constructing an institute of judicial protection of intellectual property rights has continued, this institute is one of the most controversial, and today there is no unity of theoretical or practical views on the structure of the current system of judicial protection of intellectual property rights. And even the creation of the previously unknown Ukrainian court system of the High Court of Intellectual Property, which belongs to the specialized courts, did not solve the problem, and on the contrary, scientists and practices continue to disagree with such variation of the judicial protection of intellectual property rights. One of the most problematic issues is legal regulation. It is difficult within a single court to combine the peculiarities of all processes - civil, administrative, criminal, economic.

\section{REFERENCES}

1. Agreement on Trade-Related Aspects of Intellectual Property Rights: Agreement, International Document of 15.04.1994; WTO. Official Bulletin of Ukraine. 2010. № 84. Art. 2989

2. Dihtiar A. O., Klochko A. M. The delimitation of banking and commercial secrets as objects of criminal law protection and intellectual property rights. The forum is right. No. 5. 2018.

3. Dovgan G.V. Formation and development of the Ukrainian legislation on intellectual property (historical and legal aspect). Author's abstract. to bake sciences Art. к.ю.н., from спец. 12.00.01. Lviv. 2009. with 19th

4. Commercial Procedural Code of November 6, 1991, No. 1798-XII. Verkhovna Rada of Ukraine. Information from the Verkhovna Rada of Ukraine (BP). 1992. No. 6. p.56.
5. Gumega O. Judicial protection of intellectual property rights in Ukraine as one of the principles of civil law. Theory and practice of intellectual property. No. 2. 2016. c. 88-95.

6. Study on Specialized Intellectual Property Courts: Consultants, International Intellectual Property Institute. URL: https://iipi.org/wp-content/uploads/2012/05/Study-onSpecialized-IPR-Courts.pdf.

7. The Civil Code of Ukraine dated January 16, 2003 No. 435-IV // Bulletin of the Verkhovna Rada of Ukraine (VVR), 2003, No. 40-44, p.356. 